\title{
CDISC SDTM COPD Findings About Test Code Terminology
}

National Cancer Institute

\section{Source}

National Cancer Institute. CDISC SDTM COPD Findings About Test Code Terminology.

NCI Thesaurus. Code C122007.

Terminology associated with the COPD findings about test code codelist of the Clinical

Data Interchange Standards Consortium (CDISC) Study Data Tabulation Model (SDT M). 